\title{
IBU GELONGGONG BAYINYA SAMPAI TEWAS
}

\author{
Mellynea Kezyta Nugraheni
}

\begin{abstract}
Abstrak
Ada banyak kekerasan yang terjadi terhadap seseorang, mulai dari orangtua bahkan anak kecil. Kasus kekerasan meliputi kekerasan fisik juga ditambah kekerasan psikis. Kekerasan yang semacam ini tentunya akan dapat membuat kondisi fisik sang korban terganggu, terlebih lagi dapat mempengaruhi sisi psikologi jika seorang anak yang mengalami kekerasan. Bahkan kekerasan yang terjadi seringnya menyebabkan seseorang dapat kehilangan nyawanya. Orang yang melakukan tindakan hingga menghilangkan nyawa seseorang itu disebut sebagai pembunuh. Namun diera yang modern ini, pembunuh itu tidak hanya yang tidak mengenal korbannya tetapi terdapat juga ibu kandung yang tega membunuh anaknya sendiri. Ketika seseorang secara sengaja membunuh itu berarti telah melanggar sebuah etika dimana dalam sebuah etika dimana etika berurusan dengan tindakan atau tingkah laku manusia. Ada seorang ibu yang membunuh bayinya sampai tewas. Itu juga mencakup tentang hati nurani yaitu kemampuan untuk membedakan tindakan apakah itu benar atau benar, dan hakim yang baik dan jujur. Namun karena adanya faktor dari lingkungan sekitar hati nurani bisa menjadi tumpul, bahkan dalam setiap tindakan hati nurani tidak berfungsi lagi, terlebih lagi sering membolak-balikan apa yang semestinya salah tetapi dianggap benar sehingga mereka tidak lagi memikirkan dampak dari perbuatan yang mereka lakukan. Namun, apapun yang seseorang lakukan sehingga ia melanggar maka hukum akan berjalan. Terdapat hukum yang akan dibahas dikasus kali ini. Yaitu hukum positif dan juga hukum pidans di Indonesia. Dan untuk menjawab pokok permasalahan dalam kasus ini, penulis menggunakan cara menelaah teori-teori yang ada di buku Filsafat Moral, dan asas-asas hukum serta peraturan perundang-undangan yang kasusnya berhubungan dengan pembunuhan anak.
\end{abstract}

Kata kunci : Etika, hati nurani, dan hukum. 


\section{Pendahuluan}

Pembunuhan yaitu suatu tindakan untuk menghilangkan nyawa seseorang dengan cara yang dimana tindakan itu melanggar hukum. Pembunuhan ini biasanya dilatarbelakangi oleh bermacam-macam motif. Dan pembunuhan adalah kejahatan yang paling mengerikan yang dapat dilakukan oleh setiap makhluk hidup. Karena terkadang mengambil nyawa seseorang dianggap menjadi jalan pintas untuk menyelesaikan suatu masalah atau menjadi pelampiasan kemarahan kepada individu yang lainnya. Ketika hati nurani seseorang telah mati, tanpa disadari tindakan membunuh bukanlah tindakan yang tepat untuk menyelesaikan sebuah masalah melainkan menambah panjang masalah. Dimulai dari rasa bersalah, hingga dosa yang harus dipertanggungjawabkan setelah kematiannya kelak, dan terjeratnya pelaku ke dalam sebuah ranah hukum. Pelaku pembunuhan dapat muncul dari berbagai kalangan pejabat hingga masyarakat kecil, bahkan kasus seorang ibu yang membunuh anak kandungnya sendiri.

Himpitan dalam ekonomi, kekesalan, depresi, dan faktor-faktor lainnya yang dapat menyebabkan mengapa seorang ibu sampai tega menghabisi nyawa anaknya sendiri yang telah ia perjuangkan bahkan ia mengorbankan nyawa untuk melahirkan sang anak. Padahal pada umumya, seorang ibu seharusnya memberikan kasih sayang yang penuh umtuk anaknya dalam membantu belajar, berkembang, bahkan menyediakan segala apa yang anaknya butuhkan. Bahkan sekejam-kejamnya induk singa, ia tidak akan pernah memakan anaknya sendiri.

\section{A. Apa itu Etika?}

Pengertian memaksudkan penjelasan yang lebih luas dan mendalam daripada defnisi. Terminologi "etika”secara etimologis berasal dari Yunani, "ethos", yang berarti "custom" atau kebiasaan yang berkaitan dengan tindakan atau tingkah laku manusia, juga dapat berarti "karakter" manusia (keseluruhan cetusan perilaku manusia dalam perbuatannya).

Ethos memiliki makna "anaction that is one's own", atau suatu tindakan yang dilakukan seseorang dan menjadi miliknya. Makna ethos semacam ini 
juga dimiliki oleh kata Latin, "mores”, yang darinya kata "moral”diturunkan. Dengan demikian ethical dan moral sinonim. Etika adalah flsafat moral.

Dewantara, A. (2017). Filsafat Moral (Pergumulan Etis Keseharian Hidup Manusia)

\section{B. Apa itu Hati Nurani?}

Dari mana kita mengenal hati nurani? Secara fenomenologis, dari realitas bahwa manusia selalu melakukan pertimbangan-pertimbangan dalam hidupnya. Melakukan pertimbangan artinya manusia memiliki semacam gradasi nilai-nilai yang menjadi fundamen untuk menegaskan pilihan-pilihan dan melakukan keputusan.

Hati nurani pertama-tama menyentuh pengetahuan (atau kesadaran). Pengetahuan apa? Pengetahuan dari hati. Hati nurani berarti hati manusia memiliki pengetahuan. Hati nurani ialah hati yang mengetahui. Sebenarnya proposisi "hati yang mengetahui" sama sekali tidak tepat. Soal pengetahuan tak pernah merupakan soal hati, melainkansoal akal budi (rasio). Dan sebab itu, jika dikatakan hati nurani mengetahui, maksudnya ialah hati kita memiliki semacam pertimbangan yang membimbing kehendak kita.

\section{Macam - macam hati nurani}

\section{HATI NURANI SESAT}

Hati nurani sesat (the erroneous conscience). Bagaimana cara menilai hati nurani sesat? Tomas Aquinas berkata: Bila kesesatan hati nurani invincible (tak bisa ditundukkan/tak bisa diatasi) and inculpable (tak bisa dipersalahkan/tak bisa dihukum), orang dapat luput dari perbuatan yang secara moral jahat. Artinya, bila ia berbuat jahat atas dorongan hatinya yang sesat invincible and inculpable, perbuatan jahatnya secara moral tidak bisa ditanggungkan keadaannya. Jika kesesatannya vincible (bisa diatasi) and culpable (bisa dipersalahkan),tanggung jawab perbuatan buruk/jahatnya ada pada si pelaku. Kesesatan yang culpable ialah kesesatan mengenai apa yang harus diketahui oleh seorang pribadi (jadi dia mestinya tahu), atau kesesatan itu mengalir dari kelalaian atau kesembronoan pada pihak si pelaku (misalnya, karena kesesatan itu dibiasakan). Bila kesesatan itu berhubungan dengan apa yang harus 
diketahui. Dengan kata lain, tentang apa yang semestinya dia tahu, tetapi dia tidak mau tahu atau membiarkan diri tidak tahu, dia jelas bersalah.

Kesesatan adalah vincible apabila subjek, pada waktu itu, dapat mengoreksinya. Kalau kemungkinan itu sama sekali tidak ada, karena tidak tahu atau karena tidak melihat relevansi moralitasnya, kesesatannya menjadi invincible. Kesesatan adalah culpable apabila itu merupakan produk dari pemanfaatan kebebasannya secara jahat. Menjadi culpable apabila si pelaku bersikukuh atau bertahan atau sengaja membiarkan diri dalam kesesatannya.

Dewantara, A. (2017). Filsafat Moral (Pergumulan Etis Keseharian Hidup Manusia).

\section{HATI NURANI BIMBANG}

Doubtful conscience (hati nurani bimbang). "A person never has a doubtful conscience, for when he doubts he does not know (he has not scientia) and, consequently, he has not that knowledge of the morality of his action which is called his conscience (he has not conscientia)." Hati nurani bimbang berarti pengetahuannya tidak pasti. Hati nurani tidak pernah bimbang, karena jika bimbang orang tidak memiliki pengetahuan moralitas dari tindakannya.

Dewantara, A. (2017). Filsafat Moral (Pergumulan Etis Keseharian Hidup Manusia).

Dalam bimbingan rohani, bila dalam keraguan besar, jangan mengambil keputusan yang berhubungan dengan perkara yang besar. Bila hati nurani dalam kebimbangan, mereka tidak berada pada kondisi yang dapat dipertanggungjawabkan untuk melakukan perkara-perkara besar. Yang harus dilakukan: Mendandani dan memperbaiki kondisi hati nurani semacam ini. Kalau ragu-ragu, keragu-raguannya harus disembuhkan! Macam-macam keraguan (dubium): dubium iuris (ketidaktahuan yang berhubungan dengan hukum, misalnya: saya ragu-ragu akan isi hukum tertentu), dan dubium facti (keraguan yang berhubungan dengan fakta, misalnya: saya ragu-ragu akan kenyataan tertentu). 


\section{HATI NURANI TUMPUL}

Hati nurani ini dapat diartikan sebagai hati nurani yang mana kurang peka terhadap nilai-nilai kebenaran sehingga lama-lama kesetiannya pada hati nurani menjadi tumpul. Penyebab ketumpulan : materialisme, sekuralisme, konsumerisme.

\section{HATI NURANI SKRUPEL}

Orang yang memiliki hati nurani ini dihantui oleh perasaan untuk tidak berdosa dalam hal yang sekecil-kecilnya secara ekstrim(skrupel).

\section{Hukum}

Tahukah kita? Hukum terdapat dua sisi. Hukum yang berlaku di dalam masyarakat kita mengatur hidup bersama, mengikat aneka kesepakatan, mewajibkan tindakan-tindakan yang merupakan penjabaran kesepakatan dan melarang setiap pelanggaran. Dan hukum untuk memberi sanksi kepada orang yang bersalah dan akhirnya jika terbukti bersalah maka seseorang harus masuk bui. Namun sebelum itu lebih baik kita mengerti apa arti dari hukum yang terdapat disetiap negara.

Dewantara, A. (2017). Filsafat Moral (Pergumulan Etis Keseharian Hidup Manusia).

Hukum menurut Plato, ialah seperangkat peraturan-peraturan yang tersusun secara baik serta teratur yang sifatnya mengikat hakim dan masyarakat.

Hukum menurut Achmad Ali, seperangkat norma tentang sesuatu yang benar dan salah, yang dibuat serta diakui eksisteninya oleh pemerintah, baik dalam bentuk aturan tertulis ataupun tidak, terikat sesuai dengan kebutuhan masyarakat secara menyeluruh, dan dengan sanksi bagi yang melanggar norma tersebut.

Hukum menurut Mr. E.M. Meyers, paturan yang mengandung pertimbangan kesusilaan. Hukum ditujukan kepada perilaku manusia dalam masyarakat yang menjadi pedoman bagi para penguasa Negara dalam menjalankan tugas.

Hukum dalam bahasa Latin, "lex." Lex berasal dari (1) "ligare”: mengikat; (2) "legere”: menghimpun, membaca. Mana yang lebih tepat dari keduanya, bukan soal. 
Hukum adalah itu yang mengikat, namun sekaligus merupakan itu yang kita baca sebagai aneka peraturan yang dihimpun bersama. Apakah hukum? Hukum berikut ini adalah pengertian hukum (positif) yang digagas oleh Tomas Aquinas. Hukum positif artinya hukum yang diletakkan/diberlakukan dalam masyarakat. Disebut positif bukan untuk mengatakan lawan negatif. Positif memaksudkan yang diberlakukan/diletakkan (dari “ponere-posui-positus," arti: meletakkan). Hukum positif juga disebut hukum sipil. 


\section{PEMBAHASAN}

\section{Pembahasan Kasus}

Kasus pembunuhan yang terjadi di Jalan Kepa Timur Raya, Kebun Jeruk, Jakarta Barat, pada Jumat, 18 Oktober 2019 menyisakan cerita pilu. Ibu berinisial NP, tega menggelongong anak kandungnya, ZNL, yang berusia 2,5 bulan dengan air galon. Kapolsek Kebun Jeruk, AKP Erick Sitepu, mengatakan, berdasarkan pemeriksaan forensik, ZNL tewas karena kelebihan cairan di dalam paru-parunya. Diketahui, korban merupakan salah satu anak kembar pelaku.

"Jadi saat pelaku mau memberikan makan ke korban, korban hanya malah minta minum saja. Pelaku kesal dan mengambil cangkir dari galon untuk diminumkan ke korban sampai berkali-kali, hingga delapan cangkir air putih," kata Erick. Bocah balita itu menangis dan menolak perlakuan NP. Tapi, NP terus memaksa dan mendekap hidung korban. "Setelah korban lemas dan perutnya membesar korban kemudian diletakkan ke lantai oleh pelaku," kata dia. Akibat tindakan itu ZNL tidak sadarkan diri. NP yang melihat kondisi anaknya mencari ke klinik yang terdekat. "Kemudian pelaku mengganti baju korban yang basah dan meminta tolong warga untuk membawa korban ke rumah sakit dan dinyatakan meninggal dunia," ujar dia.

Saat ditanya polisi, NP sempat mengelak telah membunuh anaknya. Tapi, NP akhirnya mengakui kalau dia tega membunuh anaknya karena depresi dengan ancaman perceraian yang dibuat sang suami. Dia melampiaskan kegelisahan itu ke anaknya. "Jadi memang diduga pelaku mengalami tekanan baik dari suami dan mertua. Dan pelaku sempat diancam suaminya akan diceraikan karena membeda-bedakan anaknya, mengingat korban ini sempat tinggal bersama mertua kondisinya lebih kurus dibanding kembarannya," ujar dia.

Sementara itu, NP menyesal telah melakukan tindakan pembunuhan itu. Dia mengatakan, sebetunya sangat sayang kepada ZNL. "Saya menyesal. Saya depresi saat itu karena masalah keluarga. Saya sayang (dengan korban). Emang waktu itu saya tidak terkontrol emosi saya, lagi kesal sama suami saya," kata NP. NP berdalih dirinya tidak berniat membunuh sang anak. Niatnya waktu itu hanya ingin melampiaskan emosi. Dia pun mencekoki anaknya sampai delapan cangkir air mineral yang dituangnya dari galon. "Saya enggak kepikiran (membunuh) waktu itu saya lagi butek lagi benar-benar stres, kenapa tibatiba melakukan hal itu saya juga bingung," ujar NP. 


\section{Pembahasan}

Motif pembunuhan oleh NP terhadap bayi berinisial ZNL adalah depresi dan terdapat ancaman perceraian. Berdasarkan motif pembunuhan yang dilakukan oleh NP bahwa awalnya anaknya waktunya untuk makan namun anaknya meminta untuk minum. Dan akhirnya pelaku (NP) membawakan anaknya minum di sebuah cangkir. Dan sang anak meminumnya, namun hal tidak biasa dilakukan oleh sang pelaku ke anaknya. Dimana anaknya diberikan minum hingga delapan kali. Kita dapat melihat bahwa direct voluntary adalah kehendak si pelaku itu sendiri. Dengan demikian direct voluntary adalah cetusan dari manusia sebagai subjek dari tingkah lakunya. Menghendaki untuk memutuskan suatu tindakan merupakan tindakan untuk mengomunikasikan dirinya dalam tindakan tersebut. Dan terlebih lagi ketika sang korban menolak, pelaku memaksa dan mendekap hidung sang korban. Kita melihat dimana seorang ibu seharusnya memiliki hati nurani untuk tidak menyakiti anak yang telah ia lakukan. Lalu ketika sang pelaku melakukan hal itu, termasuk di hati nurani manakah ia berada? Yaitu hati nurani sesat, Dewantara, A. (2017). Filsafat Moral (Pergumulan Etis Keseharian Hidup Manusia). (Bila kesesatan itu berhubungan dengan apa yang harus diketahui. Dengan kata lain, tentang apa yang semestinya dia tahu, tetapi dia tidak mau tahu atau membiarkan diri tidak tahu, dia jelas bersalah.) dimana sang pelaku memiliki hati nurani yang sesat dan tidak berpikir panjang dahulu sebelum menghabisi nyawa anaknya yang akhirnya pelaku menuruti emosinya. Pelaku juga memberi pernyataan bahwa ia melakukan ini karena akan diceraikan oleh suaminya karena anaknya kurus. Namun seharusnya ia tidak melakukan hal itu. Hanya karena hal itu seringnya hati nurani yang sesat akhirnya menjebak manusia kedalam hal sifatnya negatif.

Dewantara, A. (2017). Filsafat Moral (Pergumulan Etis Keseharian Hidup Manusia). Hukum adalah itu yang mengikat, namun sekaligus merupakan itu yang kita baca sebagai aneka peraturan yang dihimpun bersama. Hukum Kodrat yang memuat perintah dan larangan, dan yang berasal dari akal budi. Dengan demikian dapat disimpulkan bahwa Hukum Kodrat merupakan akal budi. Namun jika hukum positif tidak memiliki jerat tertentu, itu juga masih tetap disebut sebagai hukum sipil. Aquinas menggagas hokum (yang adalah soal perintah dan larangan) sebagai:

i) Ordo rationis atau ordinance of reason (tatanan akal budi). Yang dimaksud dengan akal budi, oleh Aquinas, ialah recta ratio atau right reason. Manusia sejauh manusia memiliki akal budi sehat, artinya memiliki segala apa 
yang perlu untuk berpikir dan menghendaki yang benar bagi dirinya (kesadaran bahwa dirinya adalah makhluk Tuhan) dan bagi sesamanya yang lain (kesadaran akan kodrat sosialitasnya).

ii) Tatanan akal budi ini dimaksudkan untuk mengejar bonum commune (atau the common good)-kesejahteraan umum. Aquinas mengatakan elemen kodrat hukum yang lain, yaitu bahwa hukum memiliki target untuk mengejar kesejahteraan umum.

iii) Sumber dan tatanan akal budi ini berasal dari instansi/pribadi yang bertindak sebagai penanggung jawab atas kesejahteraan umum.

iv) Sebagai hukum tatanan akal budi ini harus dipromulgasikan/diberlakukan. Bila mana hukum berlaku sebagai hukum? Bila hukum itu dipromulgasikan, diberlakukan oleh dia yang memegang tanggung jawab suatu pemerintahan.

Ketika kita melihat hukum diatas yaitu berdasarkan rasio atau hukum positif untuk mengatur setiap perilaku tanpa jerat. Namun apa yang dilakukan oleh pelaku telah melanggar semua hukum positif yang seharusnya dilakukan setiap manusia, bahkan ia melakukan suatu tindakan untuk menghilangkan nyawa seseorang dengan cara yang melanggar hukum, maupun yang tidak melanggar hukum ini disebut sebagai pembunuhan. Karena perbuatan pelaku maka ia harus terjerat sebuah pasal hukum dimana ini bukan lagi mengerti tentang bagaimana ia depresi, atau ancaman dari suaminya. Maka pelaku dikenai:

Pasal 44 ayat 3, Pasal 5 huruf a Undang-Undang (UU) Nomor 23 Tahun 2004 tentang Penghapusan Kekerasan Dalam Rumah Tangga atau Pasal 80 ayat 3 dan 4 Undang-Undang Nomor 23 Tahun 2003 tentang Perlindungan Anak.

Dimana dalam ini ancaman hukuman UU Penghapusan Kekerasan Dalam Rumah Tangga maksimal 15 tahun penjara atau denda sebesar Rp45.000.000.

Sedangkan UU tentang Perlindungan Anak, ancaman hukumannya pidana penjara selama 10 tahun dan ditambah sepertiga dari ketentuan karena yang melakukan perbuatan itu adalah orangtuanya sendiri. 


\section{DAFTAR PUSTAKA}

Dewantara, A. (2017). Filsafat Moral (Pergumulan Etis Keseharian Hidup Manusia)

Dewantara, A. (2017). Filsafat Moral (Pergumulan Etis Keseharian Hidup Manusia).

Dewantara, A. (2017). Filsafat Moral (Pergumulan Etis Keseharian Hidup Manusia).

https://id.wikipedia.org/wiki/Pembunuhan

https://www.dream.co.id/unik/ibu-gelonggong-anak-kandung-dengan-galon-air-191029t.html

https://www.yuksinau.id/pengertian-hukum-menurut-para-ahli/ 